\title{
Drought-induced production of reactive oxygen species and antioxidants activity of four local upland rice cultivars in Central Sulawesi, Indonesia
}

\author{
RUSLAN BOY ${ }^{1,2, \boldsymbol{\nu}}$, DIDIK INDRADEWA², EKA TARWACA SUSILA PUTRA ${ }^{2}$, BUDIASTUTI KURNIASIH ${ }^{2}$ \\ ${ }^{1}$ Assessment Institute for Agricultural Technology of Central Sulawesi. Jl. Palu-Kulawi Street Km.15, Watubula, Regency of Sigi, Central Sulawesi, \\ Indonesia. Tel.: +62-451-482546, Fax.: +62-451-482549, `email: boyruslan73@yahoo.co.id \\ ${ }^{2}$ Department of Agronomy, Faculty of Agriculture, Universitas Gadjah Mada. Jl. Flora, Bulaksumur, Sleman 55281, Yogyakarta, Indonesia
}

Manuscript received: 28 February 2020. Revision accepted: 15 May 2020.

\begin{abstract}
Boy R, Indradewa D, Putra ETS, Kurniasih B. 2020. Drought-induced production of reactive oxygen species and antioxidants activity of four local upland rice cultivars in Central Sulawesi, Indonesia. Biodiversitas 21: 2555-2565. Drought can be the most severe threat to the production of crop in the world. This water deficit condition may cause a considerable decrease in yield grain of upland rice. Present study was conducted to figure out the level of ROS production and antioxidant activity on upland rice cultivars under drought stress. The experiment was performed using randomized completely block design with two factors, i.e. four cultivars of upland rice (Habo, Hiwanggu, Sunggul, and Lambara) and watering interval (once in one, two, four and eight days). The results showed that there was interaction between cultivars and watering intervals. Drought tolerant cultivars of Habo and Sunggul had higher activities of SOD, POD, AAred as well as $\alpha$-Toch with lower content on free radicals of $\mathrm{O}_{2}{ }^{-}$and $\mathrm{H}_{2} \mathrm{O}_{2}$; whereas non-drought tolerant cultivars of Hiwanggu and Lambara exhibited higher production of $\mathrm{O}_{2}{ }^{-}$and $\mathrm{H}_{2} \mathrm{O}_{2}$ and lower level of SOD, POD, AAred as well as $\alpha-$ Toch. It could be concluded that the optimum soil moisture affecting maximum activities of SOD, POD, AAred as well as $\alpha$-Toch and minimum content of $\mathrm{O}_{2}{ }^{-}$and $\mathrm{H}_{2} \mathrm{O}_{2}$ was around $15.88-27.56 \%$ in range which was equal to 50.88-87.38\% of field capacity.
\end{abstract}

Keywords: Antioxidant, drought, Oryza sativa, reactive oxygen species

\section{INTRODUCTION}

Paddy is one of important cereal crops for human main food worldwide (Kumar et al. 2014). It may be planted in dryland. agroecosystem depending on water supply from rainfall and extremely susceptible to drought (Basu et al. 2017). Drought becomes one of the most serious constraints for crop production throughout the world (Kumar et al. 2018). This water deficit situation causes a considerable decline in yield grain of upland rice (Guimaraes et al. 2013). Drought stress interrupts the balance in the formation of reactive oxygen species (ROS) and activity of oxidative defense. When the formation of ROS exceeds the activity of cell oxidative defense, peroxidation rate of lipid membrane increases (Anjum et al. 2011). ROS is abundantly produced by crops under biotic and abiotic pressures (Atkinson and Urwin 2012). The effect of ROS accumulation can interrupt the enzymatic metabolism and cell structure causing plant death (Phung et al. 2011). ROS affecting oxidative stress are triplet $\left(3 \mathrm{O}_{2}\right)$, singlet $\left({ }^{1} \mathrm{O}_{2}\right)$, anion superoxide $\left(\mathrm{O}_{2}^{-}\right)$, hydroxyl radical ( $\mathrm{OH}$ ), and hydrogen peroxide $\left(\mathrm{H}_{2} \mathrm{O}_{2}\right)$ (Choudhury et al. 2017).

Drought-tolerant rice plants are characterized by the capability to adapt and tolerate the structure and biochemical traits through activation of oxidative defense mechanisms (Swapna and Shylaraj 2017). Unfavorable environmental conditions may enable the plant cell to activate the antioxidant protection systems (Jovicic et al. 2018). A set of mechanisms is found in plants to minimize the dangerous impacts (Hirayama and Shinozaki 2010; Hu and Xiong 2014; Xiong et al. 2018). Defense mechanism in the crop for restricting the damage caused by ROS is by increasing antioxidants, either enzymatic or non-enzymatic antioxidants. These antioxidants have a role in protecting the crop from damage due to oxidative stress. Enzymatic antioxidants are superoxide dismutase (SOD) and peroxide dismutase (POD), while non-enzymatic ones are ascorbic acid and alpha-tocopherol (Miller et al. 2010).

Central Sulawesi is one of provinces in Indonesia where most farmers cultivate local upland rice. Some cultivars can grow well in areas with limited rainfall. The developed upland rice is the genetic resource of the local area that has been cultivated for generations as a source of economic activity. It is also an important food crop to meet the need for rice as well as to support food security and sustainable agriculture. There is lack of information regarding enzymatic and non-enzymatic antioxidants on local cultivar upland rice of Central Sulawesi under drought stress. Therefore, this research was conducted to study drought defense mechanism on upland rice cultivars from Central Sulawesi correlating with the accumulation of ROS activity (such as $\mathrm{O}_{2}^{-}$and $\mathrm{H}_{2} \mathrm{O}_{2}$ ), antioxidant of SOD and POD, reduced form of ascorbic acid (AAred) as well as alphatocopherol ( $\alpha$-Toch). 


\section{MATERIALS AND METHODS}

\section{Plant material}

This study used four local upland rice cultivars from Palu, Central Sulawesi. The local upland rice cultivars were Habo, Sunggul, Hiwanggu, and Lambara. Habo cultivar representing high yield drought-tolerant, Sunggul for low yield drought-tolerant, Hiwanggu for high yield nondrought tolerant, and Lambara for low yield non-drought tolerant. These cultivars were commonly cultivated by local farmers in Central Sulawesi. They were selected based on screening of 20 cultivars generating those categories which were determined using stress sensitivity index (SSI).

\section{Field experiment}

The field experiment was performed in randomized completely block design in polyethylene house at Faculty of Agriculture, Universitas Gadjah Mada, from May until September 2018 (one season experiment). The altitude of research location was about $100 \mathrm{~m}$ asl. During growth period, climate condition was dry season, average temperature of $25.75^{\circ} \mathrm{C}$ as well as average humidity of $79.82 \%$.

One seed of each local rice cultivars was directly sown in a polybag of $35 \times 35 \mathrm{~cm}^{2}$ in size containing $10 \mathrm{~kg}$ of entisol soil and fertilizer. The inorganic fertilizers dose was SP-36 with dose of $25 \mathrm{~kg} \mathrm{ha}^{-1}\left(0.10 \mathrm{~g} \mathrm{P}^{-1}\right.$ polybag $\left.{ }^{-1}\right)$, Urea

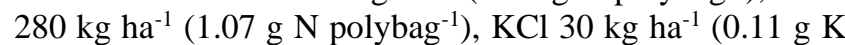
polybag $^{-1}$ ), and organic fertilizer were cattle dung about $2000 \mathrm{~kg} \mathrm{ha}^{-1}\left(7.69 \mathrm{~g} \mathrm{polybag}^{-1}\right)$.

\section{Drought stress treatment}

Treatment of drought stress was started from 16 days after sowing (das) to one week prior to harvest. The drought stress was applied by managing watering interval treatment consisted of once in one, two, four, and eight days which equal to soil moisture of $31.54 \%, 27.85 \%$, $23.36 \%$, and $13.41 \%$, respectively. Soil moisture under field capacity was $33.34 \%$ and permanent wilting point was $8.14 \%$.

Soil moisture was measured using gravimetric method with oven drying (ISRIC 1993). Five kilograms of air-dried soil samples were dried in the oven at $105^{\circ} \mathrm{C}$ for 3 hours. After cooled in desiccator the weight of oven-dried soil samples was measured. The loss of weight was noted as soil water content. The analysis was conducted at 12 weeks-old after planting in Laboratory of Soil Science, Universitas Gadjah Mada, Yogyakarta. The soil moisture was calculated with the following formula:

Water content $(\%)=($ soil water content/weight of soil sample) $\times 100$

Correction factor of water content $(\mathrm{fk})=100 /(100-$ water content)

\section{Drought stress sensitivity index analysis}

Tolerant indicator against drought stress was determined using drought sensitivity index:

$$
\text { Index of stress sensitivity }(\mathrm{SSI})=\sqrt{\frac{1-\mathrm{Ys} / \mathrm{Yp}}{1-\mathrm{Y} \bar{s} / \mathrm{Y} \bar{p}}}
$$

Ys is yield of a cultivar on stress condition (watering in every eight days), Yp is yield of a cultivar under non-stress condition (watering every day), $\mathrm{Y} \overline{\bar{s}}$ is the average yield of all cultivars under stress condition, $\mathrm{Y} \overline{\bar{p}}$ is of the average yield of all cultivars under non-stress condition (Fernandez 1992). Criteria for a drought-tolerant cultivar is indicated by SSI value $<0.5$ and moderate with $0.5<$ SSI $<1$ and sensitive with SSI $>1$ (Fischer and Maurer 1978).

\section{Free radicals and antioxidants analysis}

Plants free radicals and antioxidants analysis were determined at early generative stage, i.e. 12 weeks after sowing (84 das). This analysis was carried out in Laboratory of Joined Research, Faculty of Biology, Universitas Gadjah Mada, Yogyakarta. Free radicals and antioxidants were observed on the first leaf under rice flag leaf. The free radical groups observed in this study were $\mathrm{O}_{2}{ }^{-}$and $\mathrm{H}_{2} \mathrm{O}_{2}$ activities. Antioxidants content analyzed was superoxide dismutase (SOD), peroxide dismutase POD, reduced form of ascorbic acid (AAred), and alphatocopherol $(\alpha$-Toch).

\section{Superoxide}

Superoxide was measured using method of Malecka et al. (2014); with some modifications. A $0.5 \mathrm{~g}$ of fresh leaves of paddy was ground and transferred into test tubes and added with $7 \mathrm{~mL}$ of $50 \mathrm{mM}$ phosphate buffer $(\mathrm{pH} 7.8)$ containing $0.05 \%$ NBT and $10 \mathrm{mM} \mathrm{NaN3}$. The mixture was incubated under dark conditions at room temperature for $5 \mathrm{~min}$. Two milliliters of solution was heated in water bath at $85^{\circ} \mathrm{C}$ for $10 \mathrm{~min}$ and then cooled in ice for $5 \mathrm{~min}$. The absorbance value of solution was analyzed at $\lambda$ $589 / 580 \mathrm{~nm}$. Level of $\mathrm{O}_{2}$ was notified in a $\lambda 580 \mathrm{~g}^{-1}$ fresh weight of samples.

\section{Hydrogen peroxide}

This analysis used method of Bouazizi et al. (2007); with some modifications. A $0.5 \mathrm{~g}$ of fresh leaves of paddy was ground, homogenized into cooled $5 \mathrm{~mL} 0.1 \%$ TCA and centrifuged under $12,000 \mathrm{rpm}$ and $4^{\circ} \mathrm{C}$ for $15 \mathrm{~min}$. Supernatant was collected to determine $\mathrm{H}_{2} \mathrm{O}_{2}$ content. Reaction mixture consisted of $0.5 \mathrm{~mL}$ of supernatant, 0.5 $\mathrm{mL}$ of $10 \mathrm{mM}$ phosphate buffer $(\mathrm{pH} 7.0)$ and $1 \mathrm{~mL}$ of $1 \mathrm{M}$ $\mathrm{KI}$ solution. Its value was measured at $\lambda 390 \mathrm{~nm}$. The $\mathrm{H}_{2} \mathrm{O}_{2}$ content was determined according to its standard curve (100-500 nmol mL-1).

\section{Superoxide dismutase}

This parameter was analyzed using modified NBT method of Beyer and Fridovich (1987). A $0.2 \mathrm{~g}$ of fresh leaves of paddy was ground, homogenized with $2 \mathrm{~mL}$ of 50 $\mathrm{mM}$ phosphate buffer ( $\mathrm{pH}$ 7.8) containing 2 mM EDTA, $9.9 \mathrm{mM}$ L-methionine, $55 \mu \mathrm{M}$ NBT and $0.025 \%$ Triton$\mathrm{X} 100$. Twenty microliters of sample extract were collected and added with $20 \mu \mathrm{L}$ of $1 \mathrm{mM}$ riboflavin into reaction mixture, wrapped with aluminum foil, and then illuminated with $15 \mathrm{~W}$ fluorescent lamp at approximately $20 \mathrm{~cm}$ distance for $10 \mathrm{~min}$. Similar sample extract was placed under dark condition and used as Blanco sample. Absorbance sample was immediately observed using 
spectronic $21 \mathrm{D}$ at $560 \mathrm{~nm}$ wavelength. The activity of SOD enzymes was notified with unit/g protein. Sample was determined using standard curve of pure SOD.

\section{Peroxide dismutase}

It was measured using method of Saravanan et al. (2004); with several modifications. Five grams of fresh leaves of paddy was ground and homogenized for $2 \mathrm{~min}$ in vortex with $0.1 \mathrm{M}$ Na-phosphate buffer $(\mathrm{pH} 6.5)$ solution and the filtrate was filtered using filter paper. The collected filtrate was centrifuge at $5000 \mathrm{rpm}$ and $4^{\circ} \mathrm{C}$ for $5 \mathrm{~min}$. Five hundred microliter of supernatant was collected and reacted with $1.5 \mathrm{~mL}$ reagent (consisting of $10 \mathrm{~mL}$ of $0.5 \mathrm{M}$ pyrogallol added with $15.2 \mathrm{~mL}$ of $0.066 \mathrm{M}$ phosphate buffer and finalized with aquadest for final volume of 1000 $\mathrm{mL}$ ). For cuvet sample, $500 \mu \mathrm{L}$ of supernatant was reacted with $1.5 \mathrm{~mL}$ of reagent and $0.5 \mathrm{~mL}$ of $1 \% \mathrm{H}_{2} \mathrm{O}_{2}$. All sample mixtures were vortexed, and their absorbance was analyzed using spectrophotometer at $420 \mathrm{~nm}$ wavelength.

\section{Reduced form of ascorbic acid}

This parameter was analyzed using method of Ribeiro et al. (2012); with required modifications. One gram of fresh leaves of paddy was ground and homogenized with 2 $\mathrm{mL}$ of cooled $5 \%$ TCA (w/v). Homogenate was centrifuged at $4,000 \mathrm{rpm}$ and $4^{\circ} \mathrm{C}$ for $10 \mathrm{~min}$. Supernatant was transferred into microtube and centrifuged at $12^{\prime} 000 \mathrm{rpm}$ and $4^{\circ} \mathrm{C}$ for $20 \mathrm{~min}$. One milliliter of extract was transferred into test tubes containing $1 \mathrm{~mL}$ of $200 \mathrm{nM}$ phosphate buffer ( $\mathrm{pH} 7.4$ ), and then incubated in water bath at $42{ }^{\circ} \mathrm{C}$ for $15 \mathrm{~min}$. After incubation, $200 \mu \mathrm{L}$ of $2 \%$ TCA (w/v), $200 \mu \mathrm{L}$ of $8.4 \% \mathrm{H}_{3} \mathrm{PO}_{4}(\mathrm{w} / \mathrm{v}), 200 \mu \mathrm{L}$ of $0.8 \% 2.2$ dipyridyl $(\mathrm{w} / \mathrm{v})$, and $0.3 \% \mathrm{FeCl}_{3}(\mathrm{w} / \mathrm{v})$ were sequentially added into same test tubes. The mixture was homogenized using vortex for $5 \mathrm{~s}$ and its absorbance was observed at $\lambda 525 \mathrm{~nm}$. The preparation of Blanco solution used a similar procedure to test solutions without any addition of leaves. The concentration of AAred was calculated using linear equation of standard curve which was created with the concentration of 0-5 nM AAred in 5\% TCA 5\% (w/v). The solution was injected with HPLC.

\section{Alpha-tocopherol}

This analysis used method of Baker et al. (1980); with required modifications. One gram of freeze-liquid nitrogen of paddy leaves was gently ground and homogenized with $20 \mathrm{~mL}$ of mixture of petroleum, ether, and ethanol (2:1:6). Homogenate was centrifuged twice at $4,000 \mathrm{rpm}$ and $4{ }^{\circ} \mathrm{C}$ for $20 \mathrm{~min}$. One milliliter of supernatant was mixed with $200 \mu \mathrm{L}$ of $0.8 \% 2.2$ dipyridyl (w/v) in ethanol. The mixture was incubated under darkroom for $5 \mathrm{~min}$. Its absorbance was viewed at $\lambda 525 \mathrm{~nm}$. The preparation of Blanco solution used a similar procedure to test solutions without any addition of leaf extract. Concentration of $\alpha$-Toch was calculated with linear equation of created standard curve. The solution was injected with HPLC.

\section{Data analysis}

The normality test of data was analyzed using the Kolmogorov test and Q-Q plot (Mocanda et al. 2014) if the data was not homogenous yet. Analysis of covariance was conducted to evaluate the effect of plant genotypes (local rice cultivars) and drought stress treatment on the reactive oxygen species (ROS) and antioxidants (Hinkelman and Kempthorne 2008). The relationship between ROS and antioxidants was analyzed using Pearson correlation (Bhattacharyya and Johnson 1977). All analysis was performed using the PROC GLM and PROC CORR in SAS 9.4 (SAS Institute 2013).

\section{RESULTS AND DISCUSSION}

\section{Soil moisture}

The correlation between watering interval and soil moisture indicated that the soil field capacity condition $(\mathrm{pF}$ 2.54 ) in this study had soil moisture content of $33.34 \%$ and permanent wilting point $(\mathrm{pF} 4.2)$ at soil moisture of $8.14 \%$ equal to field capacity of $24.42 \%$ (Figure 1 ).

The treatments of watering intervals affected the soil moisture content and field capacity in the experimental sites (Table 1). The available soil moisture and field capacity tended to decrease following the reduction of watering interval, while the decrease of soil moisture was getting higher from treatment of once in a day to once in eight days watering intervals.

Soil moisture is affected by some processes occurring in the land-atmosphere interface, including water infiltration, water flow, evaporation, heat and gas exchange, infiltration of soluble substances, erosion as well as soil texture (Garnaud et al. 2017). Soil moisture has important role in the cycle of terrestrial water and agriculture, under main applications such as the monitoring of crop growth and management of hydrogeology (Palombo et al. 2019).

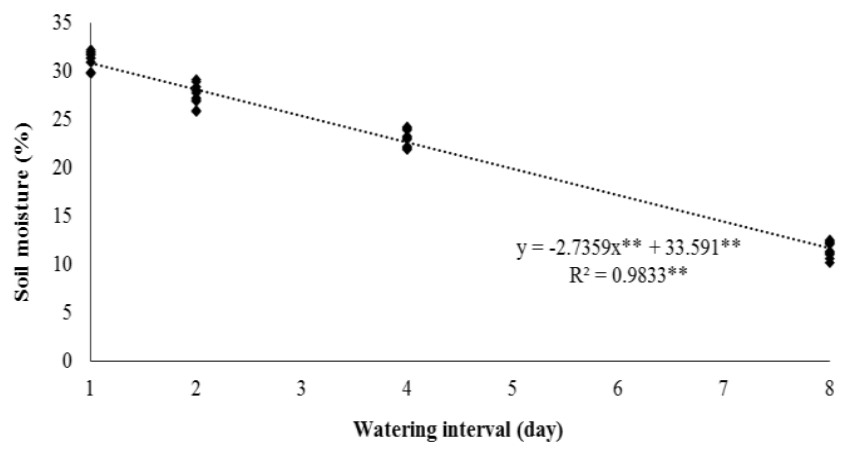

Figure 1. Relationship between watering interval and soil moisture content

Table 1. Soil moisture contents with corresponding field capacity under various watering intervals

\begin{tabular}{lccc}
\hline $\begin{array}{c}\text { Treatment of } \\
\text { watering interval }\end{array}$ & $\begin{array}{c}\text { Available soil } \\
\text { moisture (\%) }\end{array}$ & $\begin{array}{c}\text { Field } \\
\text { capacity } \\
(\boldsymbol{\%})\end{array}$ & $\begin{array}{c}\text { Decrease of soil } \\
\text { moisture (\%) }\end{array}$ \\
\hline Once in one day & 31.54 & 94.60 & 5.40 \\
Once in two days & 27.85 & 83.53 & 11.70 \\
Once in four days & 23.36 & 70.07 & 16.12 \\
Once in eight days & 13.41 & 40.22 & 42.59 \\
\hline
\end{tabular}


Table 2. Index of stress sensitivity (SSI) of local upland rice cultivars based on yield parameter

\begin{tabular}{|c|c|c|c|c|c|c|}
\hline \multirow{2}{*}{ Cultivar } & \multicolumn{4}{|c|}{ Yield Hasil (g) per grove under four levels of soil moisture } & \multirow[b]{2}{*}{ SSI value } & \multirow[b]{2}{*}{ Category } \\
\hline & $31.54 \%$ & $27.85 \%$ & $23.36 \%$ & $13.41 \%$ & & \\
\hline Habo & 27.83 & 29.52 & 31.54 & 25.69 & 0.30 & Drought tolerant \\
\hline Sunggul & 14.57 & 15.92 & 17.03 & 13.78 & 0.48 & Drought tolerant \\
\hline Hiwanggu & 24.41 & 24.84 & 26.14 & 9.50 & 1.51 & Non-drought tolerant \\
\hline Lambara & 13.51 & 13.78 & 14.11 & 5.43 & 1.84 & Non-drought tolerant \\
\hline
\end{tabular}

\section{Stress sensitivity index}

Analysis of stress sensitivity index (SSI) using yield parameter revealed that Habo and Sunggul cultivars had SSI value less than 0.5 , referring to drought-tolerant cultivars (Table 2). Meanwhile, Hiwanggu and Lambara cultivars were categorized into non-drought tolerant cultivars since their SSI values were more than 1 . Habo and Hiwanggu were considered as high-yield drought and nondrought tolerant cultivars with range of yield approximately 25.69-31.54 g per grove and 9.50-26.14 g per grove, respectively; while Sunggul and Lambara were grouped into low-yield drought and non-drought cultivars with the yield of 13.78-17.03 g per grove and 5.43-14.11 g per grove in range, respectively. Overall, the minimum and maximum yields were found on soil moisture levels of 13.41 and $23.36 \%$, respectively. Various responses between drought and non-drought tolerant cultivars indicated the diversity in sensitivity level against drought stress.

\section{Impact of drought on superoxide}

There was an interaction between cultivar and soil moisture on the activity of $\mathrm{O}_{2}^{-}(\mathrm{p}<0.01 * *)$ (Figure 2). In general, Habo and Sunggul cultivars belonging to droughttolerant category formed lower $\mathrm{O}_{2}{ }^{-}$than that of Hiwanggu and Lambara categorized into non-drought tolerant cultivars under all soil moisture contents. On the early stage of stress treatment with soil moisture of 31.54$13.41 \%$, drought-tolerant cultivars of Habo and Sunggul did not show the significant alteration in the $\mathrm{O}_{2}{ }^{-}$activity . The shift in $\mathrm{O}_{2}{ }^{-}$activity was not found on non-drought tolerant cultivars of Hiwanggu and Lambara under decrease of soil moisture around $31.54-23.36 \%$. but it was recorded on the soil moisture of $13.41 \%$. The increasing of $\mathrm{O}_{2}{ }^{-}$activity was $10.26,8.00,30.77$, and $23.08 \%$ in Habo, Sunggul, Hiwanggu, and Lambara cultivars, respectively.

The results exhibited that the activities of $\mathrm{O}_{2}{ }^{-}$on drought-tolerant cultivars of Habo and Sunggul cultivar were lower than those on non-drought tolerant cultivars of Hiwanggu and Lambara, either under optimum or minimum soil moisture conditions (Table 3). The field capacity was also recorded higher on non-drought tolerant cultivars of Hiwanggu and Lambara than that on drought cultivars of Habo and Sunggul.

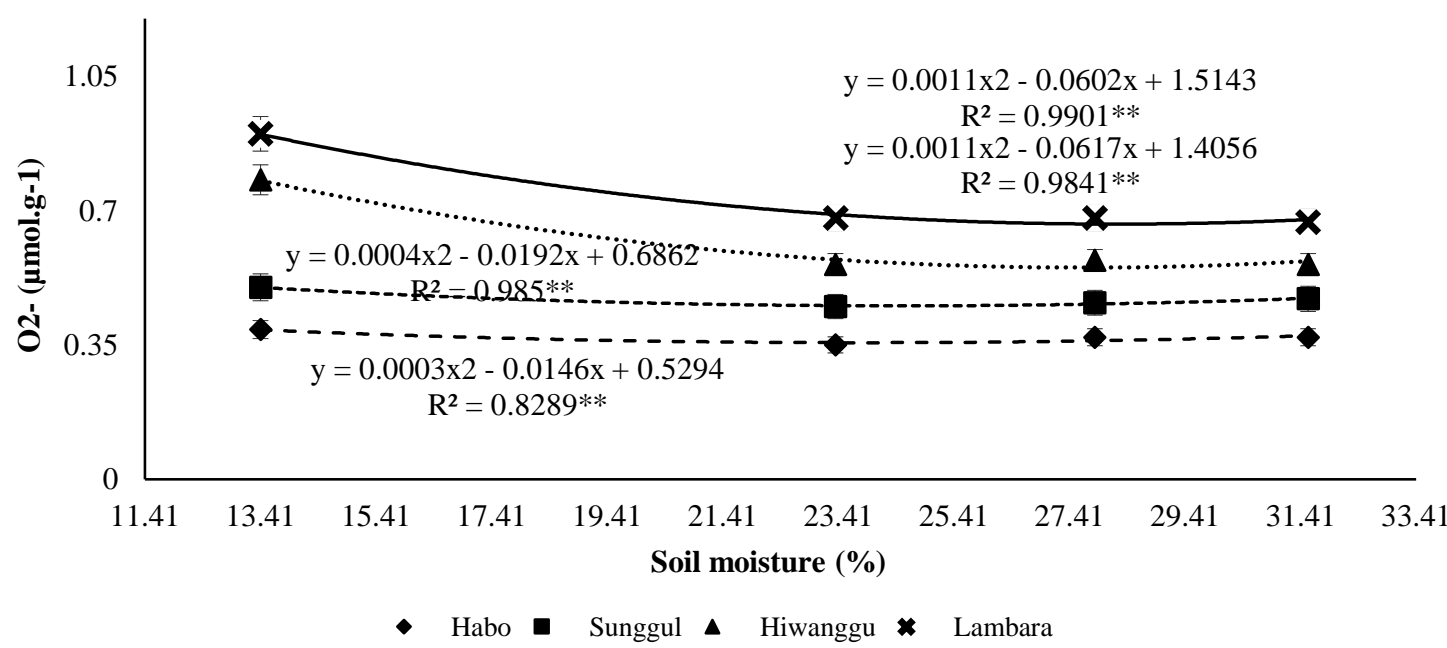

Figure 2. Relationship between soil moisture with activity of $\mathrm{O}_{2}^{-}$on four cultivars of upland rice 
Table 3. Activity of $\mathrm{O}_{2}^{-}$on four local upland rice cultivars under optimum and minimum soil moisture conditions

\begin{tabular}{|c|c|c|c|}
\hline Cultivar & Optimum soil moisture (\%) & Minimum soil moisture (\%) & Field capacity $(\%)$ \\
\hline Habo & $13.41\left(\mathrm{O}_{2}^{-}\right.$maximum $\left.0.39 \mu \mathrm{mol}^{-1} \mathrm{~g}^{-1}\right)$ & $24.34\left(\mathrm{O}_{2}^{-}\right.$minimum $\left.0.35 \mu \mathrm{mol}^{-1} \mathrm{~g}^{-1}\right)$ & 77.17 \\
\hline Sunggul & $13.41\left(\mathrm{O}_{2}^{-}\right.$maximum $\left.0.50 \mu \mathrm{mol}^{-1} \mathrm{~g}^{-1}\right)$ & $24.00\left(\mathrm{O}_{2}^{-}\right.$minimum $\left.0.46 \mu \mathrm{mol}^{-\mathrm{g}^{-1}}\right)$ & 76.09 \\
\hline Hiwanggu & $13.41\left(\mathrm{O}_{2}^{-}\right.$maximum $\left.0.54 \mu \mathrm{mol} . \mathrm{g}^{-1}\right)$ & $28.04\left(\mathrm{O}_{2}^{-}\right.$minimum $\left.0.78 \mu \mathrm{mol} . \mathrm{g}^{-1}\right)$ & 88.90 \\
\hline Lambara & $13.41\left(\mathrm{O}_{2}^{-}\right.$maximum $0.70 \mu$ mol. $\left.\mathrm{g}^{-1}\right)$ & $27.27\left(\mathrm{O}_{2}^{-}\right.$minimum $0.91 \mu$ mol. $\left.\mathrm{g}^{-1}\right)$ & 86.46 \\
\hline
\end{tabular}

Different responses between drought-tolerant and nondrought tolerant cultivars on $\mathrm{O}_{2}^{-}$activity under drought stress treatment due to the tolerant cultivars had capability in developing tolerant mechanism by suppressing $\mathrm{O}_{2}$ activity at all soil moisture level compared to droughtsensitive cultivars. The decrease of $\mathrm{O}_{2}^{-}$activity on Hiwanggu and Lambara, the drought-sensitive cultivars, at soil moisture of $13.41 \%$ level was probably caused by the accumulation of toxic $\mathrm{O}_{2}^{-}$in target cells so that the rolling enzymes in antioxidative system was failure to control the rate of $\mathrm{O}_{2}^{-}$activity under secure level. Previous studies documented that plants had antioxidative defense mechanisms to control number of ROS in safe range, consisting of antioxidant enzymatic and antioxidant nonenzymatic systems (Atkinson and Urwin 2012). Drought stress would induce oxidative stress in plant cells due to high electron-leakage reducing $\mathrm{O}_{2}$ during photosynthesis and respiration process so that ROS was increasing (Murshed et al. 2013).

\section{Effects of drought on hydrogen peroxide}

Generally, drought-tolerant cultivars, Habo, and Sunggul, formed a lower $\mathrm{H}_{2} \mathrm{O}_{2}$ than those of non-drought tolerant cultivars, Hiwanggu and Lambara, at all soil moisture levels $(\mathrm{p}<0.01 * *)$ (Figure 3$)$. In Habo and Sunggul cultivars, the alteration of soil moisture at all treatment levels did not cause a significant shift in $\mathrm{H}_{2} \mathrm{O}_{2}$ activity. Contrarily, the reduction of soil moisture from $31.54 \%$ to $13.41 \%$ affected the significant increase of $\mathrm{H}_{2} \mathrm{O}_{2}$ activity on Hiwanggu and Lambara cultivars. The increasing of $\mathrm{H}_{2} \mathrm{O}_{2}$ activity was $1.13,0.25,62.03$, and $50.81 \%$ in Habo, Sunggul, Hiwanggu, and Lambara cultivars, respectively.

The results recorded higher $\mathrm{H}_{2} \mathrm{O}_{2}$ activities on nondrought tolerant cultivars of Hiwanggu and Lambara than drought-tolerant cultivars of Habo and Siwanggu, either under optimum or minimum soil moisture conditions (Table 4). Higher field capacity was documented on nondrought tolerant cultivars of Hiwanggu and Lambara than drought-tolerant cultivars of Habo and Siwanggu.

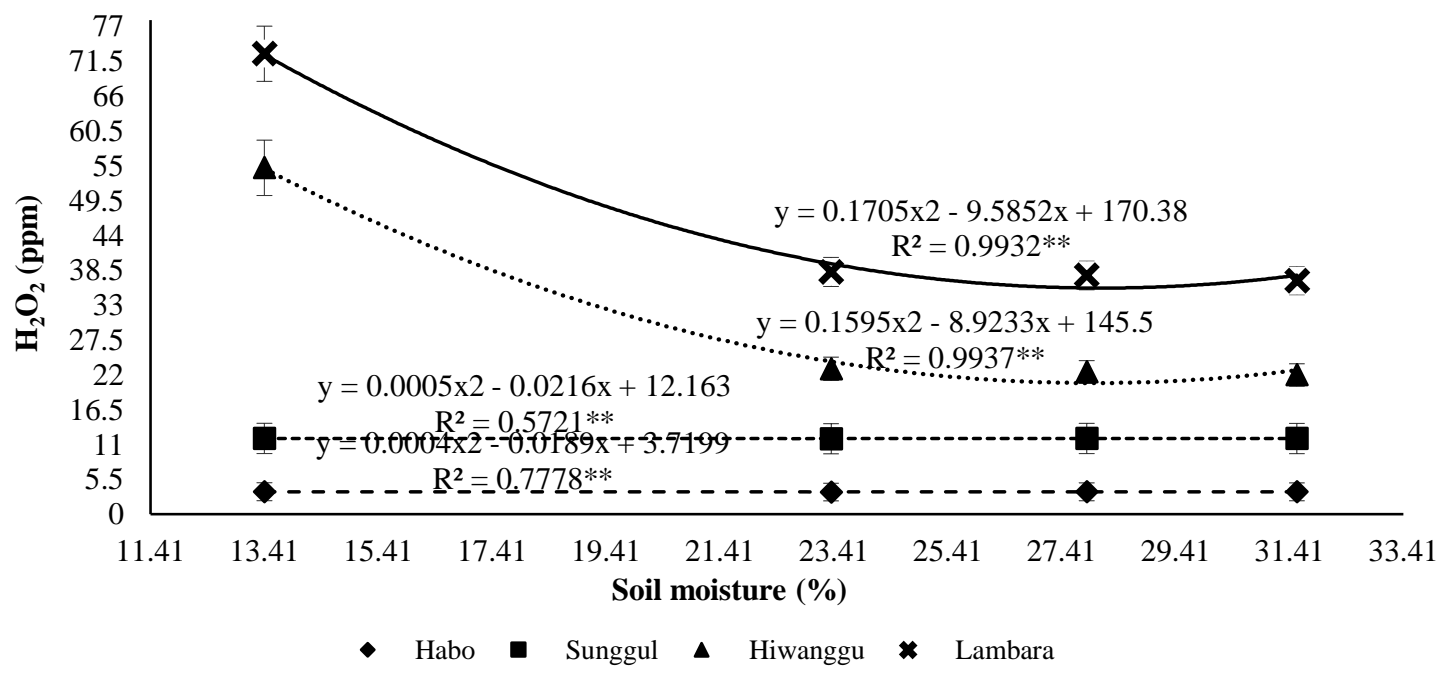

Figure 3. Relationship between soil moisture and activity of $\mathrm{H}_{2} \mathrm{O}_{2}$ on four cultivars of upland rice

Table 4. Activity of $\mathrm{H}_{2} \mathrm{O}_{2}$ on four local upland rice cultivars under optimum and minimum soil moisture conditions

\begin{tabular}{llcc}
\hline \multicolumn{1}{c}{ Cultivar } & Optimum soil moisture $(\%)$ & Minimum soil moisture $(\%)$ & Field capacity $(\%)$ \\
\hline Habo & $13.41\left(\mathrm{H}_{2} \mathrm{O}_{2}\right.$ maximum $\left.3.54 \mathrm{ppm}\right)$ & $23.63\left(\mathrm{H}_{2} \mathrm{O}_{2}\right.$ minimum $\left.3.50 \mathrm{ppm}\right)$ & 74.92 \\
Sunggul & $13.41\left(\mathrm{H}_{2} \mathrm{O}_{2}\right.$ maximum $\left.11.96 \mathrm{ppm}\right)$ & $21.60\left(\mathrm{H}_{2} \mathrm{O}_{2}\right.$ minimum $\left.11.93 \mathrm{ppm}\right)$ & 64.48 \\
Hiwanggu & $13.41\left(\mathrm{H}_{2} \mathrm{O}_{2}\right.$ maximum $\left.54.52 \mathrm{ppm}\right)$ & $27.97\left(\mathrm{H}_{2} \mathrm{O}_{2}\right.$ minimum $\left.20.70 \mathrm{ppm}\right)$ & 88.68 \\
Lambara & $13.41\left(\mathrm{H}_{2} \mathrm{O}_{2}\right.$ maximum $\left.72.50 \mathrm{ppm}\right)$ & $28.11\left(\mathrm{H}_{2} \mathrm{O}_{2}\right.$ minimum 35.66 ppm) & 89.12 \\
\hline
\end{tabular}


The increment of $\mathrm{H}_{2} \mathrm{O}_{2}$ activity on Hiwanggu and Lambara under reduction of soil moisture was caused by low capability of antioxidant defense system in controlling ROS activity at secure level under drought stress so that ROS activity in the cell was getting higher and the availability of antioxidant was getting lower due to its oxidized form. Prior works explained that higher rate of ROS formation than its degradation rate generated oxidative stress conditions (Miller et al. 2010). Hydrogen peroxide $\left(\mathrm{H}_{2} \mathrm{O}_{2}\right)$ in the plant cells can have a role as signaling molecules i.e. the defense against the stress, hormonal responses, and growth, as well as development. When exposed to environmental stress conditions, $\mathrm{H}_{2} \mathrm{O}_{2}$ production will increase. However, excessive accumulation of $\mathrm{H}_{2} \mathrm{O}_{2}$ will be toxic, thus its activity must be strictly controlled by the plants (Sharma et al. 2012). Kalanamak 3131 cultivar with drought treatment shows $47 \%$ increase of $\mathrm{H}_{2} \mathrm{O}_{2}$ concentration in comparison to without drought treatment (Shukla et al. 2012).

\section{Role of superoxide dismutase under drought}

There was interaction between drought stress treatment/soil moisture and cultivar in SOD activity $\left(\mathrm{p}<0.01^{* *}\right)$ (Figure 4). The activities of SOD were found higher on drought-tolerant cultivars of Habo and Sunggul than those on non-drought tolerant cultivars of Hiwanggu and Lambara under all soil moisture levels.

The reduction of soil moisture from $31.54 \%$ to $23.36 \%$ on Habo and Sunggul cultivars exhibited significant increase in SOD activity. There was no change in SOD activity under further soil moisture decrease. In contrast, the decrease of soil moisture from $31.54 \%$ to $23.26 \%$ on Hiwanggu and Lambara cultivars did not indicate the alteration in SOD activity yet. The significant decrease in SOD activity was found under further reduction of soil moisture. The activities of SOD subsequently decreased in the Habo, Sunggul, Hiwanggu, and Lambara cultivars approximately $4.48 \%, 2.79 \%, 73.13 \%$, and $81.45 \%$, respectively.

The results revealed that activity of SOD was higher on drought-tolerant cultivars of Habo and Sunggul than that on non-drought tolerant cultivars of Hiwanggu and Lambara, either under optimum or minimum soil moisture conditions (Table 5). Meanwhile, higher field capacity was recorded on non-drought tolerant cultivars of Hiwanggu and Lambara than that on drought-tolerant cultivars of Habo and Sunggul.

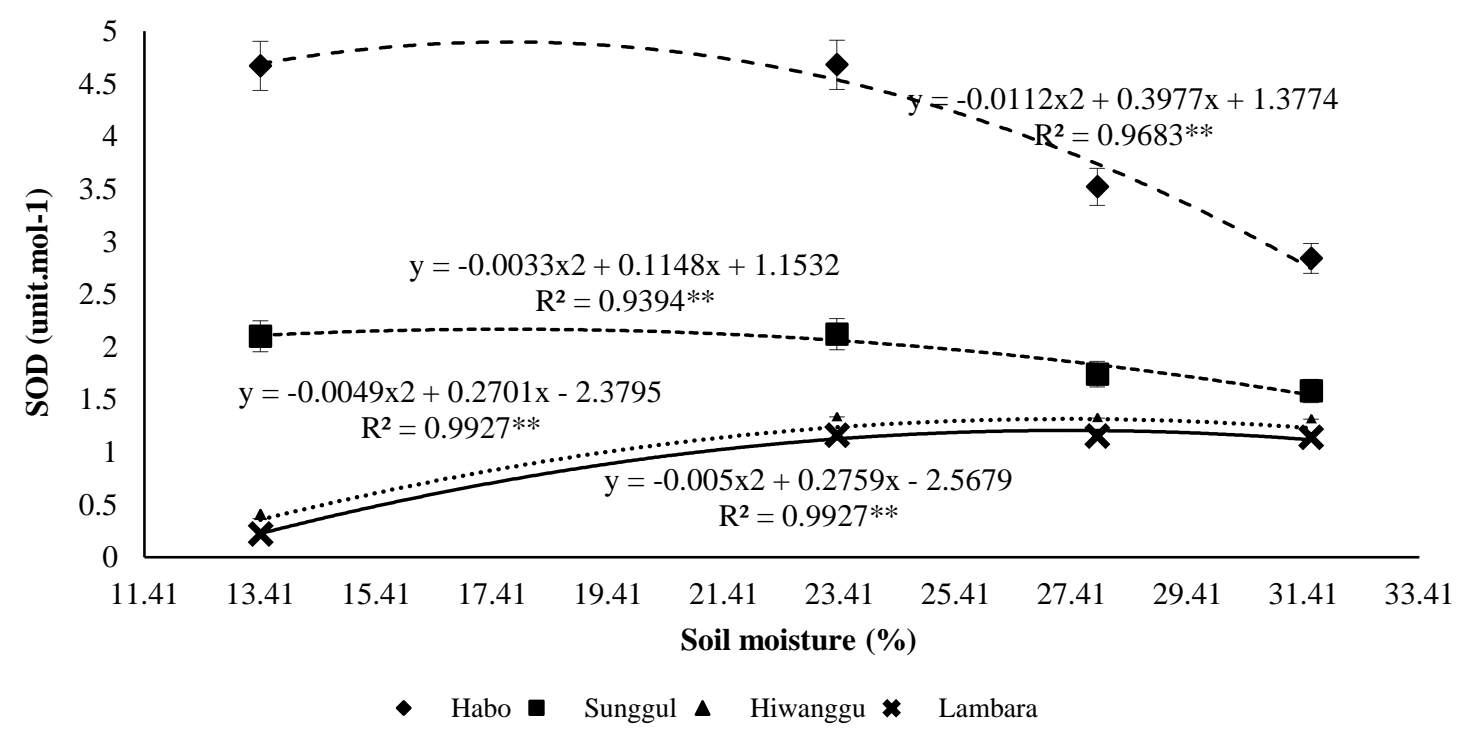

Figure 4. Relationship between soil moisture with activity of SOD on four cultivars of upland rice

Table 5. Activity of SOD on foul local upland rice cultivars under optimum and minimum soil moisture conditions

\begin{tabular}{|c|c|c|c|}
\hline Cultivar & Optimum soil moisture (\%) & Minimum soil moisture (\%) & Field capacity (\%) \\
\hline Habo & 17.76 (SOD maximum 4.91 unit. $\mathrm{mL}^{-1}$ ) & 13.41 (SOD minimum 4.69 unit.mL ${ }^{-1}$ ) & 56.31 \\
\hline Sunggul & $17.40\left(\right.$ SOD maximum 2.15 unit. $\left.\mathrm{mL}^{-1}\right)$ & 13.41 (SOD minimum 2.09 unit.mL ${ }^{-1}$ ) & 55.17 \\
\hline Hiwanggu & 27.56 (SOD maximum 1.34 unit.mL $\mathrm{mL}^{-1}$ ) & 13.41 (SOD minimum 0.36 unit.mL ${ }^{-1}$ ) & 87.38 \\
\hline Lambara & 27.59 (SOD maximum 1.24 unit. $\mathrm{mL}^{-1}$ ) & 13.41 (SOD minimum 0.23 unit.mL ${ }^{-1}$ ) & 87.47 \\
\hline
\end{tabular}


Various responses in SOD activity on drought-tolerant cultivars of Habo and Sunggul as well as non-drought tolerant cultivars of Hiwanggu and Lambara under established soil moisture due to the different mechanisms in oxidative defense systems developed by each cultivar to anticipate negative impact generated by ROS during drought stress period. Therefore, different patterns in alteration of SOD activity among cultivars indicated that their tolerance level against drought stress was determined by the increment in SOD activity. Other investigations summarized that the increase of antioxidant synthesis under stress conditions was extremely varied among species and even cultivars within one plant species (Shao et al. 2008). The SOD activity of drought-tolerant Jin23B rice powder increases after six days of drought stress treatment in comparison to the control plants. On the other hand, drought intolerant 97B rice shows earlier increasing of SOD activity after the third day of drought stress and decreasing activity on the sixth day of drought treatment in comparison to the control plant (Fu et al. 2010). The sensitivity of each cultivar can be different in drought stress depending on the resilience character of each cultivar (Cabello et al. 2013).

\section{Role of peroxide dismutase under drought}

Interaction between different rice cultivars and soil moisture has occurred against POD activity $\left(\mathrm{p}<0.01^{* *}\right)$
(Figure 5). The drought-tolerant cultivars, Habo and Sunggul, formed higher POD than those of non-drought tolerant cultivars of Hiwanggu and Lambara under all soil moisture levels.

The reduction of soil moisture from $31.54 \%$ to $23.36 \%$ on drought-tolerant cultivars of Habo and Sunggul generated a significant increment in POD activity. However, there was no significant alteration in POD activity under further reduction of soil moisture at $13.41 \%$ level. Contrarily, there was significant alteration in POD activity on non-drought tolerant cultivars of Hiwanggu and Lambara under reduction of soil moisture from $31.54 \%$ to 23.36\%: however further decrease of soil moisture at $13.41 \%$ level caused significant reduction in POD activity. The decreases in POD activity in the Habo, Sunggul, Hiwanggu, and Lambara cultivars were 9.52\%, 5.56\%, $66.67 \%$, and $83.33 \%$, respectively.

The results found that drought-tolerant cultivars of Habo and Sunggul had higher activities of POD than those on non-drought cultivars of Hiwanggu and Lambara, either under optimum or minimum soil moisture conditions (Table 6). However, the higher field capacity was documented on non-drought cultivars of Hiwanggu and Lambara under such conditions.

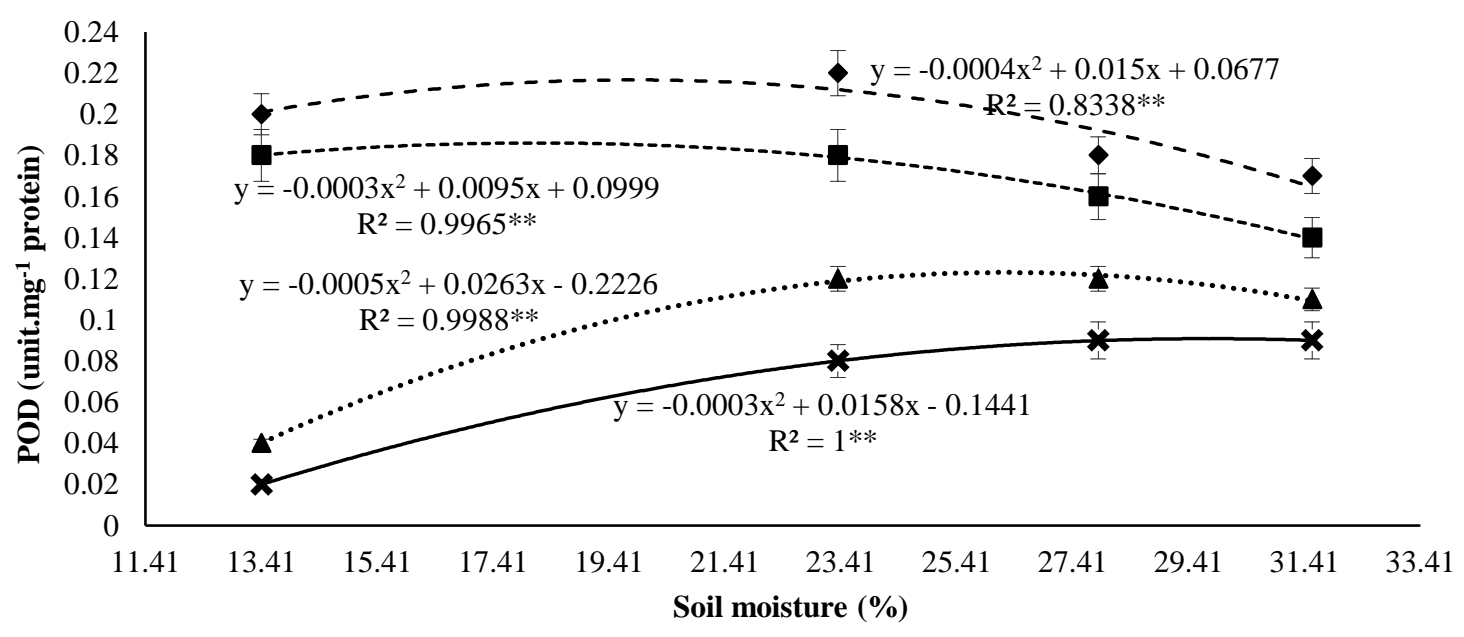

- Habo $\boldsymbol{\square}$ Sunggul $\boldsymbol{\Delta}$ Hiwanggu $\boldsymbol{*}$ Lambara

Figure 5. Relationship between soil moisture with POD activity on four cultivars of upland rice

Table 6. Activity of POD on four local upland rice cultivars under optimum and minimum soil moisture conditions

\begin{tabular}{|c|c|c|c|}
\hline Cultivar & Optimum soil moisture (\%) & Minimum soil moisture (\%) & Field capacity $(\%)$ \\
\hline Habo & 18.78 (POD maximum 0.21 unit.mg ${ }^{-1}$.protein) & 13.41 (POD minimum 0.19 unit.mg ${ }^{-1}$.protein) & 59.54 \\
\hline Sunggul & 15.88 (POD maximum 0.18 unit.mg ${ }^{-1}$.protein) & 13.41 (POD minimum 0.17 unit.mg ${ }^{-1}$.protein) & 50.35 \\
\hline Hiwanggu & 26.30 (POD maximum 0.12 unit.mg ${ }^{-1}$.protein) & 13.41 (POD minimum 0.04 unit.mg ${ }^{-1}$.protein) & 83.39 \\
\hline Lambara & 26.34 (POD maximum 0.06 unit.mg ${ }^{-1}$.protein) & 13.41 (POD minimum 0.01 unit.mg $^{-1}$.protein) & 85.51 \\
\hline
\end{tabular}


At the early treatment until $23.36 \%$, drought-tolerant cultivars were stimulated to develop metabolic activity since the presence of ROS activity compared to nontolerant cultivars. Following further reduction of soil moisture at $13.41 \%$, the decrease POD activity on nondrought tolerant cultivars was caused by higher required antioxidant POD enzymatic to reduce over-expression of ROS activity. Former work noted that POD enzyme was widely allocated in plant cells and as important protein in ROS detoxification in chloroplast (Foyer and Shigeoka 2011). POD enzymes play a major role in reducing the $\mathrm{H}_{2} \mathrm{O}_{2}$ accumulated activity in cells (Ahmad and Haddad 2011). Research on drought-treated potato plants showed higher POD activity in comparison to the control plants (Wegener and Jansen 2013).

\section{Role of AAred under drought}

Figure 6 showed the occurrence of interaction between cultivar with soil moisture against activity of AAred $(\mathrm{p}<0.01 * *)$. The results revealed that drought-tolerant cultivars of Habo and Sunggul produced higher AAred than those of non-drought tolerant cultivars of Hiwanggu and Lambara under all soil moisture levels.

The reduction of soil moisture from $31.54 \%$ to $23.36 \%$ on Habo and Sunggul cultivars resulted in a significant increase of AAred activity. In contrast, there was no alteration in AAred activity on Hiwanggu and Lambara cultivars under similar conditions of soil moisture. The decrease of AAred activity was documented on all cultivars under further reduction of soil moisture at $13.41 \%$ level. The activities of AAred in Habo, Sunggul, Hiwanggu, and Lambara reduced by $10.02 \%, 14.32 \%, 56.44 \%$, and $54.81 \%$, respectively.

The results exhibited that the activities of AAred were higher on drought-tolerant cultivars of Habo and Sunggul than those on non-drought tolerant cultivars of Hiwanggu and Lambara either under optimum or minimum soil moisture conditions (Table 7). Meanwhile, the higher field capacity was found on non-drought cultivars of Hiwanggu and Lambara.

AAred activity under reduction of soil moisture up to $23.26 \%$ in Habo and Sunggul cultivars indicating that these cultivars had better tolerance capability against drought rather than Hiwanggu and Lambara cultivars. The activity of AAred was one of developed mechanisms to overcome the prevalence of oxidative stress. Meanwhile, the reduction of AAred activity on all cultivars following the decline of soil moisture at $13.41 \%$ was presumed due to there was increment in antioxidant requirement in reducing the increasing activity of free radicals of cell during drought stress period. Previous study reported that the Ascorbic acid could directly neutralize $\mathrm{O}^{-}$dan $\mathrm{H}_{2} \mathrm{O}_{2}$ or as substrate for APX enzyme in AA-GSH cycle (Szarka et al. 2012). AAred is an abundant antioxidant in the plant functionating to prevent cell damage due to ROS by donating electrons during drought stress (Gill and Tuteja 2010).

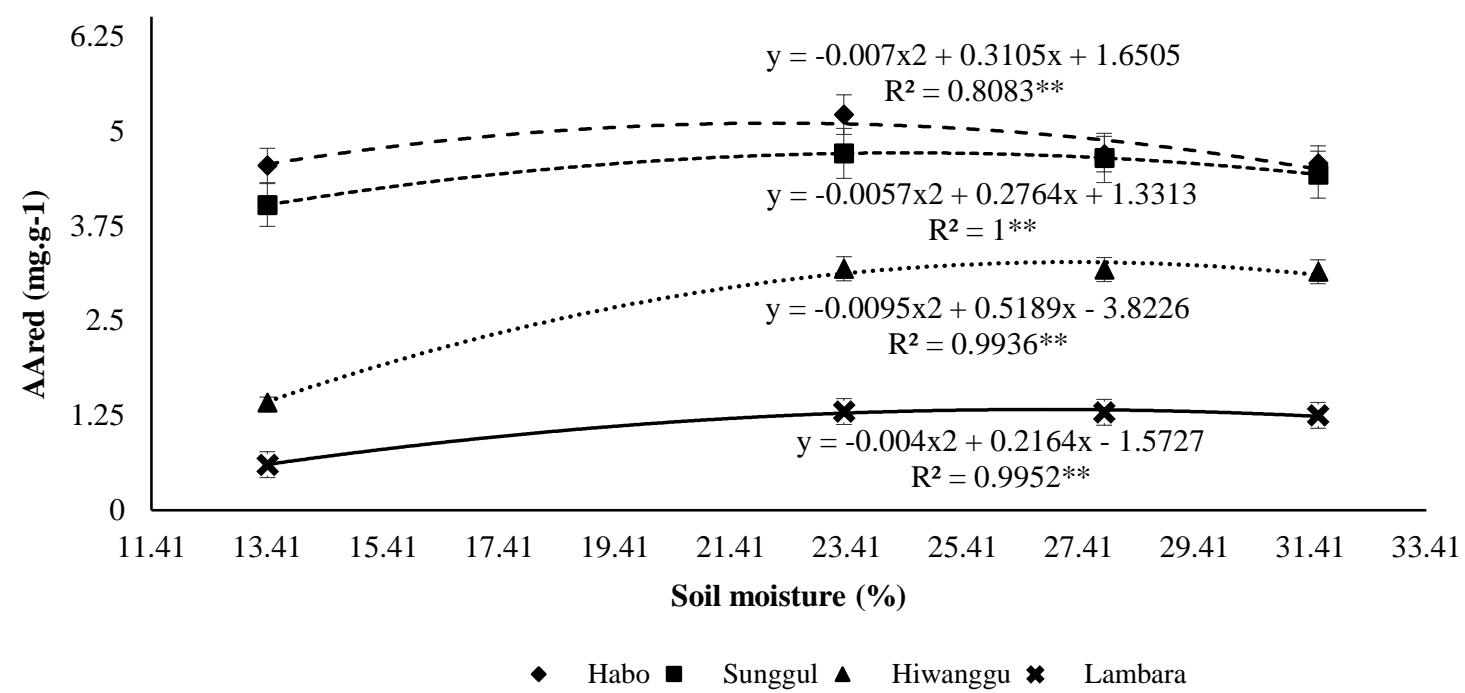

Figure 6. Relationship between soil moisture and activity of AAred on four cultivars of upland rice

Table 7. Activity of AAred on four local upland rice cultivars under optimum and minimum soil moisture conditions

\begin{tabular}{|c|c|c|c|}
\hline Cultivar & Optimum soil moisture (\%) & Minimum soil moisture (\%) & Field capacity $(\%)$ \\
\hline Habo & 22.17 (AAred maximum $5.09 \mathrm{mg} \cdot \mathrm{g}^{-1}$ ) & 13.41 (AAred minimum $4.56 \mathrm{mg} \mathrm{g}^{-1}$ ) & 70.29 \\
\hline Sunggul & 24.25 (AAred maximum $4.68 \mathrm{mg}^{-\mathrm{g}^{-1}}$ ) & 13.41 (AAred minimum $4.01 \mathrm{mg}^{-\mathrm{g}^{-1}}$ ) & 76.89 \\
\hline Hiwanggu & 27.31 (AAred maximum $3.26 \mathrm{mg}^{-1} \mathrm{~g}^{-1}$ ) &  & 86.59 \\
\hline Lambara & 27.06 (AAred maximum $1.35 \mathrm{mg}^{-\mathrm{g}^{-1}}$ ) & 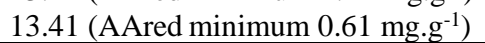 & 85.80 \\
\hline
\end{tabular}




\section{Role of alpha-tocopherol under drought}

There was interaction between cultivar with soil moisture on the activity of $\alpha$-Toch $(\mathrm{p}<0.01 * *)$ (Figure 7). The results revealed that drought-tolerant cultivars of Habo and Sunggul formed higher $\alpha$-Toch than those of nondrought tolerant cultivars of Hiwanggu and Lambara under all soil moisture levels.

The decrease of soil moisture from $31.54 \%$ to $23.36 \%$ on Habo and Sunggul cultivars showed a significant increase in $\alpha$-Toch activity. Contrarily, there was no alteration in $\alpha$-Toch activity under similar soil moisture levels on Hiwanggu and Lambara cultivars. The reduction of $\alpha$-Toch activity was recorded on all cultivars under further decrease of soil moisture at $13.41 \%$ level. The decreases of $\alpha$-Toch activity were recorded in Habo, Sunggul, Hiwanggu, and Lambara cultivars around $24.41 \%, 39.68 \%, 67.62 \%$, and $76.29 \%$, respectively.

The results showed that higher activities of $\alpha$-Toch were found on drought-tolerant cultivars of Habo and Sunggul (Table 8). Meanwhile, field capacity was higher on non-drought tolerant cultivars of Hiwanggu and Lambara.

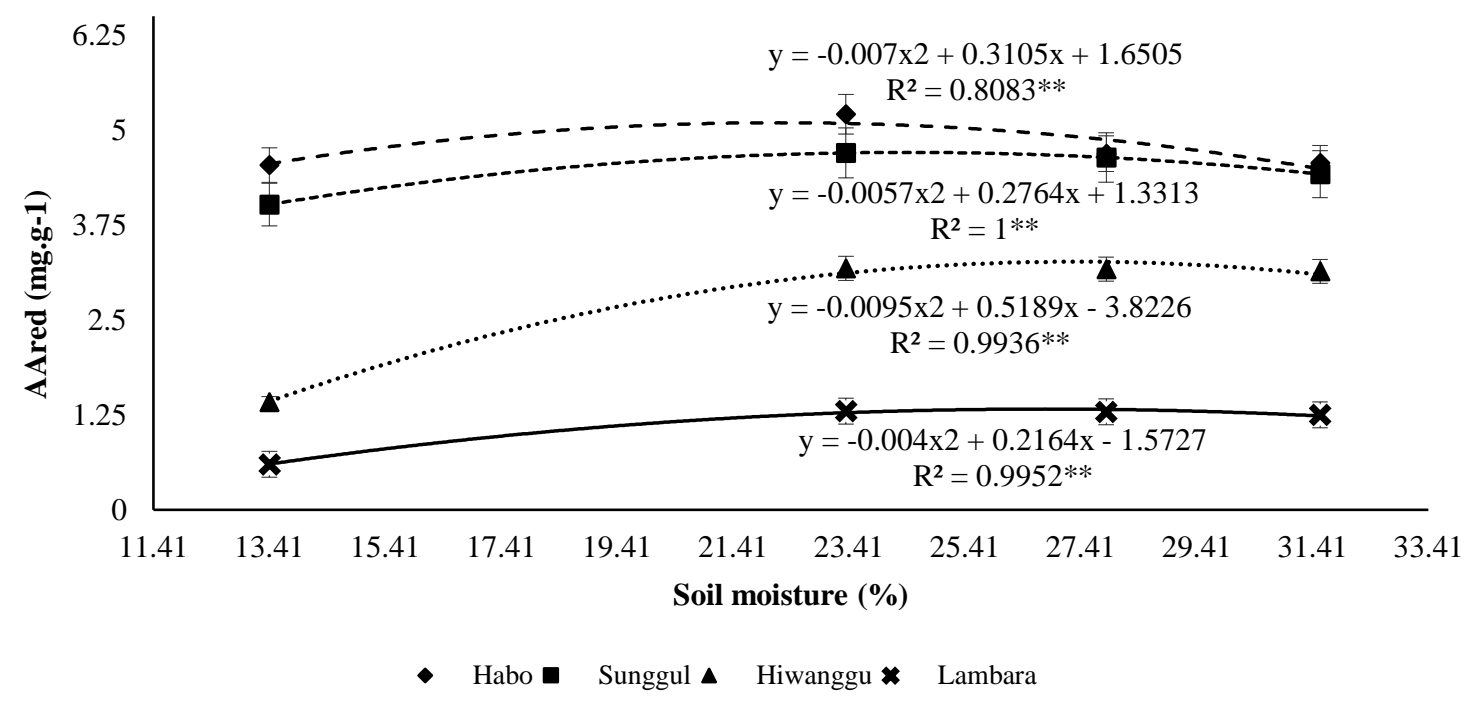

Figure 7. Relationship between soil moisture and activity of $\alpha$-Toch on four cultivars of upland rice

Table 8. Activity of $\alpha$-Toch on four local upland rice cultivars under optimum and minimum soil moisture conditions

\begin{tabular}{llll}
\hline Cultivar & Optimum soil moisture $(\%)$ & Minimum soil moisture $(\%)$ & Field capacity $(\%)$ \\
\hline Habo & $22.56\left(\alpha\right.$-Toch maximum $\left.1.70 \mathrm{mg} \cdot \mathrm{g}^{-1}\right)$ & $13.41\left(\alpha-\right.$ Toch minimum $\left.1.20 \mathrm{mg} \cdot \mathrm{g}^{-1}\right)$ & 71.53 \\
Sunggul & $24.70\left(\alpha\right.$-Toch maximum $\left.1.26 \mathrm{mg} \cdot \mathrm{g}^{-1}\right)$ & $13.41\left(\alpha-\right.$ Toch minimum $\left.0.76 \mathrm{mg} \cdot \mathrm{g}^{-1}\right)$ & 78.31 \\
Hiwanggu & $27.09\left(\alpha\right.$-Toch maximum $\left.1.05 \mathrm{mg} \cdot \mathrm{g}^{-1}\right)$ & $13.41\left(\alpha-\right.$ Toch minimum $\left.0.34 \mathrm{mg} \cdot \mathrm{g}^{-1}\right)$ & 85.89 \\
Lambara & $27.56\left(\alpha\right.$-Toch maximum $\left.0.97 \mathrm{mg} \cdot \mathrm{g}^{-1}\right)$ & $13.41\left(\alpha-\right.$ Toch minimum $\left.0.23 \mathrm{mg} \cdot \mathrm{g}^{-1}\right)$ & 87.38 \\
\hline
\end{tabular}

Table 9. Correlation between free radical groups with antioxidants

\begin{tabular}{|c|c|c|c|c|c|c|}
\hline & $\mathrm{O}_{2}^{-}$ & $\mathbf{H}_{2} \mathrm{O}_{2}$ & SOD & POD & AAred & a-Toch \\
\hline $\mathrm{O}_{2}^{-}$ & 1 & & & & & \\
\hline $\mathrm{H}_{2} \mathrm{O}_{2}$ & $0.985^{* *}$ & 1 & & & & \\
\hline SOD & $-0.838 * *$ & $-0.789 * *$ & 1 & & & \\
\hline POD & $-0.943 * *$ & $-0.941 * *$ & $0.867 * *$ & 1 & & \\
\hline AAred & $-0.949 * *$ & $-0.932 * *$ & $0.765^{* *}$ & $0.921 * *$ & 1 & \\
\hline$\alpha$-Toch & $-0.897 * *$ & $-0.874 * *$ & $0.807 * *$ & $0.849 * *$ & $0.801 * *$ & 1 \\
\hline
\end{tabular}

Note: $* *$ correlation at $\alpha$ level $=0.01 \%$. 
The local drought-tolerant cultivars, Habo and Sunggul, had higher tolerance level against drought stress than Hiwanggu and Lambara cultivars due to the formation of higher $\alpha$-Toch activity. The similar responses revealed by all cultivars under reduction of soil moisture at $13.41 \%$ and causing the decrease of $\alpha$-Toch activity illustrated high use of that antioxidant to support functions in oxidative defense system under drought stress condition and the decrease of biosynthesis rate in $\alpha$-Toch during drought stress due to ROS accumulation exceeding tolerance level of oxidative defense in a cultivar under given soil moisture level. The role of $\alpha$-Toch under drought stress had been proven on previous research that furthermore, a-Toch could functionate to reduce ROS molecules, particularly $\mathrm{O}_{2}^{-}$and $\mathrm{OH}$, under stress condition as well as might inhibit the process of lipid peroxidation process on photosynthetic membrane ( $\mathrm{Li}$ et al. 2008). $\alpha$-tocopherol functioned in maintaining homeostasis of cellular $\mathrm{Na}^{+} / \mathrm{K}^{+}$and hormonal balance in the plant (Ellouzi et al. 2013). Accumulation of a-tocopherol indicated the presence of increment in relative water content, photosynthesis rate, and the reduction in membrane damage under oxidative stress (Ezpinosa et al. 2013).

\section{Correlation among variables}

There were significant negative correlations between antioxidant groups activity with ROS activity (Table 9). Generally, the increment of antioxidant activity caused a decrease in ROS activity. The increase in the SOD and POD enzyme activities as well as AAred and $\alpha$-Toch significantly reduced $\mathrm{O}_{2}^{-}$and $\mathrm{H}_{2} \mathrm{O}_{2}$. Drought tolerant cultivars of Habo and Sunggul were characterized with high antioxidant activities and low free radicals, whereas those of non-drought tolerant cultivars, Hiwanggu and Lambara, were indicated by low antioxidant and high free radicals.

Reactive oxygen species production will disturb the homeostasis of cell growth, depending on the quantity of ROS production. Exceeding ROS production antioxidant capacity leads cell to oxidative stress. Conversely, lower or balance ROS production with antioxidant capacity will enable cell growth. Pandev and Shukla (2015) stated that the increased activity of antioxidant defensive enzymes can represent the protective activities of the rice plants to cope with oxidative damage caused by drought conditions.

Drought tolerant cultivars of Habo and Sunggul had higher activities of SOD, POD, AAred as well as $\alpha$-Toch than those in Hiwanggu and Lambara, causing lower content of free radicals such as $\mathrm{O}_{2}^{-}$and $\mathrm{H}_{2} \mathrm{O}_{2}$ in the tolerant cultivars than those of non-drought tolerant cultivars.

In conclusion, the developed drought resistance of tested four upland rice cultivars was tolerance mechanism through the improvement of antioxidant defense system consisting of SOD, POD, AAred, and $\alpha$-Toch to prevent the reaction of free radicals of $\mathrm{O}_{2}^{-}$and $\mathrm{H}_{2} \mathrm{O}_{2}$ under drought stress condition. The optimum soil moisture causing maximum activities of SOD, POD, AAred, and $\alpha$-Toch as well as minimum content of $\mathrm{O}_{2}^{-}$and $\mathrm{H}_{2} \mathrm{O}_{2}$ was the range of $15.88-27.56 \%$ equal to field capacity of $50.88-87.38 \%$.

\section{ACKNOWLEDGEMENTS}

The grateful expression was delivered to Indonesia Agricultural Agency for Research and Development, Ministry of Agriculture for financial support of this study under contract number 209.1/Kpts/KP.320/H.1/7/2017. Authors appreciate the technical assistance of the field technicians and the Lab technicians of Soil Laboratory and Crop Production and Management Laboratory, Faculty of Agriculture, and Biology Laboratory, UGM, Yogyakarta, Indonesia.

\section{REFERENCES}

Ahmad ST, Haddad R. 2011. Study of silicon effects on antioxidant enzyme activities and osmotic adjustment of wheat under drought stress. Czech J Genet Plant Breed 47: 17-27.

Anjum SA, Saleem MF, Wang L, Bilal FM, Saeed A. 2012. Protective role of glycine betaine in maize against drought-induced lipid peroxidation by enhancing capacity of antioxidative system. Aust J Crop Sci 6: 576-583.

Atkinson NJ, Urwin PE. 2012. The interaction of plant biotic and abiotic stress: from genes to the field. J Exp Bot 63: 3523-3554.

Bhattacharyya GK, Johnson RA. 1977. Statistical Concepts and Methods. John Wiley and Sons Inc, USA.

Baker H, Frank O, De-Angelis B, Feingold S. 1980. Plasma tocopherol in man at various times after ingesting free or acetylated tocopherol. Nutr Rep Intl 21: 531-536.

Basu S, Giri RK, Benazir I, Kumar S, Rajwanshi R, Dwivedi SK, Kumar G. 2017. Comprehensive physiological analyses and reactive oxygen species profiling in drought-tolerant rice genotypes under salinity stress. Physiol Mol Biol Plants 23 (4): 837-850.

Beyer WF, Fridovich I. 1987. Assaying for superoxide dismutase activity: some large consequences of minor changes of conditions. Anal Biochem 161: 559-566.

Bouazizi H, Jouili H, Ferjani EE. 2007. Effects of copper excess on growth, $\mathrm{H}_{2} \mathrm{O}_{2}$ production, and peroxidase activities in maize seedlings (Zea mays L.). Pak J Biol Sci 10 (5): 751-756.

Cabello JV, Lodeyro AF, Zurbriggen MD. 2013. Novel perspectives for the engineering of abiotic stress tolerance in plants. Curr Opin Biotechnol 26: 62-70.

Choudhury FK, Rivero RM, Blumwald E, Mittler R. 2017. Reactive oxygen species, abiotic stress and stress combination. Plant J 90: 856867.

Ellouzi H, Hamed KB, Cela J, Müller M, Abdelly C, Munné-Bosch S. 2013. Increased sensitivity to salt stress in tocopherol deficient Arabidopsis mutants growing in a hydroponic system. Plant Signal Behav 8 (2): e23136-1 - e23136-13.

Ezpinoza A, Martín AS, López-Climent M, Ruiz-Lara S, Gómez-Cadenas A, Casaretto JA. 2013. Engineered drought-induced biosynthesis of $\alpha$ tocopherol alleviates stress-induced leaf damage in tobacco. J Plant Physiol 170: 1285-1294.

Fernandez GCJ. 1992. Effective selection criteria for assessing stress tolerance. In: Kuo C.G (Ed.) Proceedings of the international symposium on adaptation of vegetables and other food crops in temperature and water stress. Publication Tainan Taiwan.

Fischer RA, Maurer R. 1978. Drought resistance in spring wheat cultivars. I grain yield responses. Aust J Agric Res 29: 897-912.

Foyer CH, Shigeoka S. 2011. Understanding oxidative stress and antioxidant functions to enhance photosynthesis. Plant Physiol 155: 93-100.

Fu GF, Song J, Li YR, Yue MK, Xiang J, Tao LX. 2010. Alterations of panicle antioxidant metabolism and carbohydrate content and pistil water potential involved in spikelet sterility in rice under water-deficit stress. Rice Sci 17 (4): 303-310.

Garnaud C, Bélair S, Carrera M, McNairn H, Pacheco A. 2017. Fieldscale spatial variability of soil moisture and L-band brightness temperature from land surface modeling. J Hydrometeorol 18: 573589. 
Gill SS, Tuteja N. 2010. Reactive oxygen species and antioxidant machinery in abiotic stress. Plant Physiol Biochemist 48: 909-930.

Guimarães CM, Stone LF, Rangel PHN, Silva ACL. 2013. Tolerance of upland rice genotypes to water deficit. Revista Brasileira de Engenharia Agrícola e Ambiental 17 (8): 805-810.

Hinkelman K, Kempthorne O. 2008. Design and Analysis of Experiments. $2^{\text {nd }}$ eds. John Wiley and Sons, USA.

Hirayama T, Shinozaki K. 2010. Research on plant abiotic stress responses in the post-genome era: past, present and future. Plant J 61: 1041-1052.

Hu H, Xiong L. 2014. Genetic engineering and breeding of droughtresistant crops. Annu Rev Plant Biol 65: 715-741.

ISRIC. 1993. Procedures for Soil Analysis. In: Van Reeuwijk LP (eds) Technical paper, international soil reference and information centre 4th ed. Wageningen The Netherlands.

Jovicic D, Nikolic Z, Mikic A, Milosevic B, Milojevic D, Ignjatov M, Marinkovic D. 2018. Antioxidant enzymes activities in Vicia seedlings during drought stress. Ratar Povrt 55 (1): 1-5.

Kumar A, Dixit S, Ram T, Yadaw RB, Mishra KK, Mandal NP. 2014 Breeding high-yielding drought-tolerant rice: genetic variations and conventional and molecular approaches. J Exp Bot 65 (21): $6265-$ 6278 .

Kumar S, Sachdeva S, Bhat KV, Vats S. 2018. Plant responses to drought stress: Physiological, biochemical and molecular basis. In: Sharad V (eds) Biotic and abiotic stress tolerance in plants. Springer Nature Singapore Pte Ltd, Singapore.

Li Y, Wang Z, Sun X, Tang K. 2008. Current opinions on the functions of tocopherol based on the genetic manipulation of tocopherol biosynthesis in plants. J Integr Plant Biol 50 (9): 1057-1069.

Malecka A, Piechalak A, Zielinska B, Kutrowska A, Tomaszewska B. 2014. Response of the pea roots defense systems to the two element combinations of metals $(\mathrm{Cu}, \mathrm{Zn}, \mathrm{Cd}, \mathrm{Pb})$. Acta Biochimica Polonica 61 (91): 23-28

Miller G, Suzuki N, Ciftci-Yilmaz S, Mittler R. 2010. Reactive oxygen species homeostatic and signalling during drought and salinity stresses. Plant Cell Environ 33: 453-467.

Mocanda MP, Gabriels D, Cornelis WM. 2014. Data-driven analysis of soil quality parameters using limited data. Geoderma 235-236: 271278 .

Murshed R, Lopez-Lauri F, Sallanon H. 2013. Effect of water stress on antioxidant systems and oxidative parameters in fruits of tomato
(Solanum lycopersicon L, cv. Micro-tom). Physiol Mol Biol Plants 19 (3): 363-378.

Palombo A, Pascucci S, Loperte A, Lettino A, Castaldi F, Muolo MR, Santini F. 2019. Soil moisture retrieval by integrating TASI-600 airborne thermal data, worldview 2 satellite data and field measurements: Petacciato case study. J Sensors 19 (1515): 1-19.

Pandey V, Shukla A. 2015. Acclimation and tolerance strategies of rice under drought stress. Rice Sci 22 (4): 147-161.

Phung TH, Jung HI, Park JH, Kim JG, Back K, Jung S. 2011. Porphyrin biosynthesis control under water stress: sustained porphyrin status correlates with drought tolerance in transgenic rice. Plant Physiol 157: 1746-1764.

Ribeiro C, Cambraia J, Henrique P, Peixoto PHP, Meira E, Júnior F. 2012. Antioxidant system response induced by aluminium in two rice cultivars. Braz J Plant Physiol 24 (2): 107-116.

Saravanan T, Bhaskaran R, Muthusamy M. 2004. Pseudomonas fluorescens induced enzymological changes in banana roots $(\mathrm{Cv}$. Rasthali) against fusarium wilt disease. Plant Pathol J 3 (2): 72-80.

SAS Institute. 2013. SAS System for Windows 9.4. United States North Carolina SAS Institute Inc.

Shao HB, Chu LY, Shao MA, Jaleel CA, Mi HM. 2008. Higher plant antioxidants and redox signalling under environmental stresses. Comp Rend Biol 331: 433-441.

Sharma P, Jha AB, Dubey RS, Pessarakli M. 2012. Reactive oxygen species, oxidative damage, and antioxidative defense mechanism in plants under stressful conditions. J Bot 1-26.

Shukla N, Awasthi RP, Rawat L, Kumar J. 2012. Biochemical and physiological responses of rice (Oryza sativa L.) as influenced by Trichoderma harzianum under drought stress. Plant Physiol Biochemist 54: 78-88.

Swapna S, Shylaraj KS, 2017. Screening for osmotic stress responses in rice cultivars under drought conditions. Rice Sci 24 (5): 253-263.

Szarka A, Tomasskovics B, Benhegyi G. 2012. The ascorbate-glutathione$\alpha$-tocopherol triad in abiotic stress response. Int J Mol Sci 13: 44584483.

Wegener CB, Jansen G. 2013. Antioxidants in different potato genotypes: Effect of drought and wounding stress. Agriculture 3: 131-146.

Xiong H, Yu J, Miao J, Li J, Zhang H, Wang X, Liu P, Zhao Y, Jiang C, Yin Z, Li Y, Guo Y, Fu B, Wang W, Li Z, Ali J, Lia Z. 2018. Natural variation in $O s L G 3$ increases drought tolerance in rice by inducing ROS scavenging. Plant Physiol 178: 451-467. 